\title{
Detection and Antibiogram Study of Bacteria Isolated from Dried and Cooked Fish
}

\author{
Mst. Deloara Begum ${ }^{1}$, Md. Muniruzzaman ${ }^{1}$, Md. Salauddin ${ }^{2 *}$ and Md. Mostafizer Rahman' \\ ${ }^{1}$ Department of Microbiology, Faculty of Veterinary and Animal Science, Hajee Mohammad Danesh Science and Technology \\ University, Dinajpur-5200, Bangladesh; ${ }^{2}$ Department of Microbiology and Public Health, Faculty of Veterinary, Animal and \\ Biomedical Sciences, Khulna Agricultural University, Khulna-9100, Bangladesh.
}

Mst. Deloara Begum and Md. Muniruzzaman contributed equally to this work as first authors.

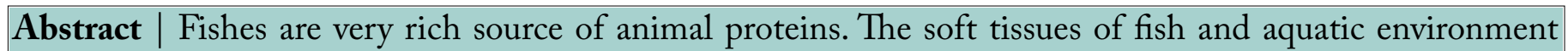
are extremely susceptible to microbial contamination. In this research a total of 79 samples were collected from different local market. In which 54 samples were from dried fish and 25 from cooked fish samples. In this research there were 18 different types of dried fish and 6 types of cooked fish were used as a sample. Laboratory work was done by different bacteriological laboratory methods and purified isolates were identified according to gram's staining reaction, colony morphology, cultural characteristics, biochemical and antibiotic susceptibility test. All most $100 \%$ dried and $20 \%$ cooked fish sample were contaminated. In this study seven different species and 168 isolates were identified from dried fish and these were Escherichia coli 21.43\% (36), Vibrio spp. 18.45\% (31), Staphylococcus spp.17.86\% (30), Pseudomonas spp.17.86\% (30), Salmonella spp.12.5\% (21), Shigella spp. 8.93\% (15) and Klebsiella spp. 2.97\% (5). In cooked fish 9 isolates were identified and species were Escherichia coli $66.66 \%$ (6) and Shigella spp. $33.34 \%$ (3). Total viable count varies from $1.28 \times 10^{7} \mathrm{CFU} / \mathrm{g}$ to $3.74 \times 10^{9} \mathrm{CFU} / \mathrm{g}$. The highest concentration was found in Loitta fish and lowest in Ruhi from dried fish. Most species of bacteria isolated were resistant to amoxicillin, penicillin-g, kanamycin, azithromycin, cefuroxime sodium, cephalexin, nalidixic acid, cephradine and erythromycin. The isolates were found to be of medical importance. Hence it is considered that a variety of bacterial species can be associated with dried fish related pathogen to animal and humans.

Editor Muhammad Abubakar, National Veterinary Laboratories, Park Road, Islamabad, Pakistan.

Received | October 09, 2021; Accepted | November 29, 2021; Published | December 17, 2021

*Correspondence | Md. Salauddin, Department of Microbiology and Public Health, Faculty of Veterinary, Animal and Biomedical Sciences, Khulna Agricultural University, Khulna-9100, Bangladesh; Email: salauddin@kau.edu.bd

Citation| Begum, M.D., M. Muniruzzaman, M. Salauddin and M.M. Rahman. 2021. Detection and antibiogram study of bacteria isolated from dried and cooked fish. Veterinary Sciences: Research and Reviews, 7(2): 134-142.

DOI | https://dx.doi.org/10.17582/journal.vsrr/2021.7.2.134.142

Keywords | Fish borne diseases, Dried fish, Cooked fish, Public health hazard, Microbial quality of dried and cooked fish

\section{Introduction}

Fons ish has become an increasingly important source of protein, necessary for the maintenance of good health. The quality of fish is of major concern to the food processors, consumers, and public health authorities (Pal et al.,2016). Fish and Fish products are not only nutritional importance but also importance in global market as foreign currency earner for a number of countries in the world (Sohana and Karim, 2016). Human food habit dramatically changes day by day on fish in the last three decades, especially in East Asia (mainly in China) and in the Near East/ North African region. Recent report shows that global 
per capita fish consumption is $20 \mathrm{~kg}$ per year which provides $6.7 \%$ of all protein consumed by human all over the world (FAO, 2016). Fish revolution also occurs in Bangladesh about 25-fold growth in farmed fish market over the last three decades (Ahmad, 2017). Bangladesh is considered one of the most suitable regions for fisheries in the world, with the world's largest flooded wetland and the third largest aquatic biodiversity in Asia after China and India (Mozumder et al., 2018). Bangladesh mainly exports ten categories of fishery products (Frozen freshwater fish, frozen marine water fish, frozen shrimp, chilled fish, live fish, dry fish, salted dehydrate, live kusia, live crab, and fish scale/shrimp scull) to more than 55 countries. Only in 2016-17, Bangladesh earns BDT 42876.40 million by exporting almost 68.31 Thousand MT of fish and fisheries products. This success is due to export of quality shrimp introducing HACCP procedure and traceability regulation according to the requirement of European Union (EU) and USA (Shamsuzzaman et al., 2017).

According to the Department of Fisheries (DoF, 2017), fisheries contribute 3.69 percent of Bangladesh's GDP and over 23 percent of agricultural GDP. With an average fish intake of 53 grams per person a day, fish now account for 60 percent of protein supply for the entire population (DoF, 2016). In Seventh Five Year Plan (7FYP) Bangladesh Government has taken 5 major goal, and the 5 th is Improved food safety (a) Good Aquaculture Practices (GAP) and Good Manufacturing Practices (GMP) at all stages of fish/shrimp supply chain to comply international market. (b) Food safety measures for domestic markets. From the food safety point of view provision of safe sound and wholesome fish and fish products are more essential for control the contamination of fish. Quality of fish deteriorates due to a complex process of physical chemical and microbial changes in the content of fish. Fish of good quality should have bacterial count less than 105 per gram. The greatest risk to human health occurs due to the consumption of raw, inadequately cooked or insufficiently processed fish, and fish products (Pal et al., 2016).

Bacteria are the main fish-borne zoonotic agents (diseases transmitted from fish to human vice versa), infection is typically acquired through abrasions, cuts, or penetrating wounds in the skin when handling infected fish or fomites (Boylan, 2011). Human infections caused by pathogens transmitted from fish or the aquatic environment are mostly depending on the season, patients contact with fish and surrounding environment, dietary habits and the immune system status of the exposed individual. The infection source may be fish kept for food or as a hobby (aquarium fish). Some bacterial species are facultatively pathogenic for both fish and humans. They may be isolated from fish without apparent symptoms of the disease. Human infections and intoxications with the following bacteria have been recorded: Mycobacterium spp., Streptococcus iniae, Photobacterium damselae, Vibrio alginolyticus, $V$. vulnificus, $V$. parahaemolyticus, V. cholerae, Erysipelothrix rhusiopathiae, Escherichia coli, Aeromonas spp., Salmonella spp., Staphylococcus aureus, Listeria monocytogenes, Clostridium botulinum, $C$. perfringens, Campylobacter jejuni, Delftia acidovorans, Edwardsiella tarda, Legionella pneumophila, and Plesiomonas shigelloides (Novotny et al., 2017). The results of numerous studies indicate that fish possess bacterial populations on or in their skin, gills, digestive tract, and light-emitting organs (Austin, 2006).

Fish borne zoonotic diseases can be transmitted directly by consuming raw and improperly cooked fish meat or indirectly via contaminated water from the surroundings of infected fish. Due to lack of available data about microbiological quality of fish it is difficult to achieve this goal. We are also facing problem to meet up the requirement $\mathrm{HACCP}$ protocol in the processing of frozen fishes for export. Therefore, the purpose of the present study was to investigate the microbiological quality of dried and cooked fish. The study also investigates the significant effect of antibiotic sensitivity pattern of the isolated bacteria. Bearing in mind the above facts the present study was undertaken with following specific objectives: (a) To isolate and identify the bacterial pathogens with the evaluation of microbial load of cooked and dried fish samples; (b) To create awareness among local beneficiaries and consumers.

\section{Materials and Methods}

\section{Study area, collection and processing of samples}

The present research work was carried out on dried and cooked fish available in the local market in Dinajpur city. All the samples were brought to the laboratory for detection and antibiogram study of bacterial pathogens from these samples. The laboratory works was conducted in the Bacteriology laboratory of the Department of Microbiology, Faculty of Veterinary 
and Animal Science, Hajee Mohammad Danesh Science and Technology University (HSTU), Dinajpur. A total 79 samples were collected from local market and different restaurant in Dinajpur city. Out of 79 samples 54 samples were dried fish and 25 were cooked fish samples. There were 18 different types of dried fish and 6 different types of cooked fish product samples. Firstly, Samples were rinsed thoroughly with sterile distilled water. Then samples were homogenized through blending with $90 \mathrm{ml}$ peptone water (Cappuccino and Sherman, 1996). Then 1-10-fold dilutions were performed (Figure 1).

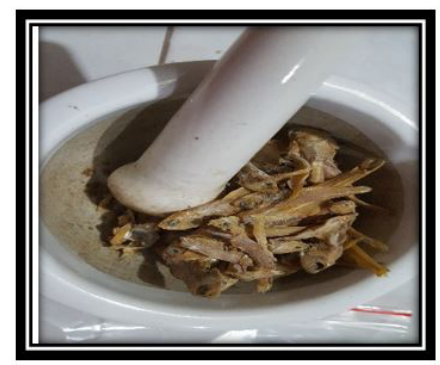

Darikana dry Fish

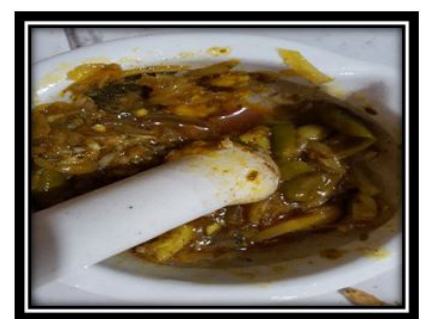

Figure 1: Preparation of dried and Cooked fish sample.

\section{Serial dilution of samples}

$10 \mathrm{~g}$ of each fish sample were weighed aseptically and homogenized in $90 \mathrm{ml}$ sterile PBS water. Then, serial dilutions were made by mixing $1.0 \mathrm{ml}$ of the suspension in $9.0 \mathrm{ml}$ sterile PBS water to obtain $10^{-1}$ dilution. The dilution was then made to $10^{-2}$, and $10^{-6}$ diluents. At first, for each of the processed samples 10 sterile test tubes were placed on a test tube holder rack containing $9 \mathrm{ml}$ of $2 \%$ buffered peptone water. $1 \mathrm{ml}$ processed sample was mixed with $9 \mathrm{ml}$ of Phosphate buffer solution in the $1^{\text {st }}$ test tube in order to make $10^{-1}$ dilution. Then $1 \mathrm{ml}$ solution from $1^{\text {st }}$ test tube mixed with $2^{\text {nd }}$ test tube, then from $2^{\text {nd }}$ test tube to $3^{\text {rd }}$ test tube and finally $5^{\text {th }}$ to $6^{\text {th }}$ test tube and $1 \mathrm{ml}$ discard from $7^{\text {th }}$ test tube by the help of pipette and in every step, mixing was done properly.

\section{Total viable count (TVC) of samples}

$50 \mu \mathrm{l}$ of each fivefold dilution was transferred and spread onto Plate Count Agar using a micropipette for each dilution for the determination of total bacterial count. The diluted samples were spread as quickly as possible on the surface of the plate. The plates were kept in an incubator at $37{ }^{\circ} \mathrm{C}$ for $24 \mathrm{hrs}$. After incubation, plates exhibiting 30-300 colonies were counted. The average number of colonies in particular dilution was multiplied by the dilution factor to obtain the total viable count. The total viable count was calculated according to ISO (1995). The results of the total bacterial count were expressed as the number of colonies forming units (CFU) per $\mathrm{ml}$ of food samples. The formula is given bellow.

\section{Number of cells per ml=number of colonies $\times$ Dilution} factor

\section{Antimicrobial sensitivity discs and susceptibility test}

To determine the drug sensitivity pattern of different bacterial isolate with different types of commercially available antimicrobial discs (Oxoid Ltd., UK) were used. The antibiotics that were tested against the selected organisms with their disc concentration are Gentamicin (GEN) $10 \mu \mathrm{g} /$ disc, Amoxicillin (AMX) $30 \mu \mathrm{g} /$ disc, Cefuroxime Sodium (CXM) $30 \mu \mathrm{g} /$ disc, Cephalexin (CN) $30 \mu \mathrm{g} /$ disc, Cefixime (CEF) $5 \mu \mathrm{g} /$ disc, Azithromycin (AZM) $30 \mu \mathrm{g} /$ disc, Erythromycin (E) $15 \mu \mathrm{g} /$ disc, Penicillin G (P) $10 \mu \mathrm{g} /$ disc, Nalidixic Acid (NA) $30 \mu \mathrm{g} /$ disc, Colistin (CL) $10 \mu \mathrm{g} /$ disc, Streptomycin (S) $10 \mu \mathrm{g} /$ disc, Kanamycin (K) $30 \mu \mathrm{g} / \mathrm{disc}$, Cefradine $(\mathrm{CH}) 25 \mu \mathrm{g} / \mathrm{disc}$. Antibiotic sensitivity assay of isolated bacteria used to determine the sensitivity or resistance of pathogenic aerobic and facultative anaerobic bacteria to various antimicrobial compounds was determined in vitro by using the standardized agar disc-diffusion method known as the Kirby Bauer (K-B) (Hudzicki, 2009).

\section{Reading plates and interpreting results}

After 24 hours of incubation, each plate was examined. If the plate was satisfactorily streaked, and the inoculum was correct, the resulting zones oh inhibition will be uniformly circular and there will be a confluent lawn of growth. If individual colonies were apparent, the inoculum was too light and the test must be repeated. The diameters of the zones of complete inhibition (as judged by the unaided eye) were measured, including the diameter of the disc. Zones were measured to the nearest whole millimeter, using sliding calipers or a ruler, which was held on the back of the inverted Petri plate. The Petri plate was held a few inches above a black, nonreflecting background and zones are measured in millimeter $(\mathrm{mm})$ from the upper surface of the agar illuminated with reflected 
light, with the cover removed (EUCAST, 2015).

\section{Results and Discussion}

The results of microbial loads, staining, cultural, biochemical, antibiotic sensitivity pattern and percentage of incidence of isolated bacteria are presented in different table and described below under the following headings.

\section{Results of cultural examinations}

Cultural characteristics of each type of bacteria isolated from different dried and cooked fish sample were studied for the determination of size, shape and colony characteristics in various bacteriological media. The staining property of primary culture of each of the different samples indicated the presence of more than one type of bacteria in the same smear. The pure cultures of the organism from each mixed culture were obtained by repeated streak plate method using different simple and selective solid media for study. The individual cultural characteristics of bacterial isolates are considered to pick the best one. Based the cultural characteristics of Klebsiella spp., Staphylococcus spp., Shigella spp., Salmonella spp., Pseudomonas spp., Vibrio spp. and $E$. coli on the media matched with (Merchant and Packer et al., 1967). All the organisms identified by microscopic examination as well as biochemical test result confirmed with (Buxton and Fraser; 1977).

\section{Result of total viable count (TVC)}

After preparation of tenfold dilution all $50 \mu 1$ sample were spread Plate Count Agar (PCA) media up to dilution $10^{-6}$. Then the number of colonies was observed and recorded (in the form of CFU/gm) of samples are presented in Table 1 for dried fish sample and Table 2 for cooked fish.

\section{Result of isolation and identification of bacteria}

Isolation and identification of bacteria was made by microscopic characteristic examination and different biochemical examination from the pure culture of the organisms. Seven species of bacteria such as Escherichia coli, Salmonella spp., Pseudomonas spp., Vibrio spp., Staphylococcus spp., Shigella spp. and Klebsiella spp. were isolated from dried fish but two species of bacteria such as Escherichia coli and Shigella spp. isolated from cooked fish respectively. Following Table 3 represent summary of bacteria isolates from dried fish samples and Table 4 of cooked fish samples.
Table 1: TVC result of dried fish sample.

December 2021 | Volume 7 | Issue 2 | Page 137

\begin{tabular}{|c|c|c|c|c|}
\hline $\begin{array}{l}\text { Local } \\
\text { name }\end{array}$ & $\begin{array}{l}\text { Dried fish name } \\
\text { (Scientific Name) }\end{array}$ & $\begin{array}{l}\text { Dilu- } \\
\text { tion }\end{array}$ & $\begin{array}{l}\text { Number of } \\
\text { colonies }\end{array}$ & $\begin{array}{l}\text { Total via- } \\
\text { ble count } \\
\text { cfu/gm }\end{array}$ \\
\hline \multirow[t]{3}{*}{ Boal } & \multirow{3}{*}{$\begin{array}{l}\text { Wallago Catfish } \\
\text { Wallago attu }\end{array}$} & $10^{-4}$ & Over 300 & TNTC \\
\hline & & $10^{-5}$ & 204 & $4 \times 10^{8}$ \\
\hline & & $10^{-6}$ & 160 & $3.2 \times 10^{9}$ \\
\hline \multirow{3}{*}{$\begin{array}{l}\text { Shol/ } \\
\text { Shoal }\end{array}$} & \multirow{3}{*}{$\begin{array}{l}\text { Snauchead Murrel/ } \\
\text { Snakehead fish } \\
\text { Channa striata }\end{array}$} & $10^{-4}$ & 212 & $4.24 \times 10^{7}$ \\
\hline & & $10^{-5}$ & 180 & $3.6 \times 10^{7}$ \\
\hline & & $10^{-6}$ & 153 & $3.06 \times 10^{9}$ \\
\hline \multirow{3}{*}{$\begin{array}{l}\text { Dari- } \\
\text { kana/ } \\
\text { Dariki }\end{array}$} & \multirow{3}{*}{$\begin{array}{l}\text { Slender rasbora } \\
\text { Rasbora daniconius }\end{array}$} & $10^{-4}$ & 240 & $4.8 \times 10^{7}$ \\
\hline & & $10^{-5}$ & 80 & $1.6 \times 10^{8}$ \\
\hline & & $10^{-6}$ & 32 & $6.4 \times 10^{8}$ \\
\hline \multirow[t]{3}{*}{ Churi } & \multirow[t]{3}{*}{ Churi Fish } & $10^{-4}$ & 88 & $1.76 \times 10^{7}$ \\
\hline & & $10^{-5}$ & 60 & $1.2 \times 10^{8}$ \\
\hline & & $10^{-6}$ & 38 & $7.6 \times 10^{8}$ \\
\hline \multirow[t]{3}{*}{ Ilish } & \multirow{3}{*}{$\begin{array}{l}\text { Hilsa Shad/Hilsa fish } \\
\text { Tenualosa ilisha }\end{array}$} & $10^{-4}$ & 76 & $1.52 \times 10^{7}$ \\
\hline & & $10^{-5}$ & 40 & $8.0 \times 10^{7}$ \\
\hline & & $10^{-6}$ & 32 & $6.4 \times 10^{8}$ \\
\hline \multirow{3}{*}{$\begin{array}{l}\text { Baspa- } \\
\text { ta }\end{array}$} & \multirow{3}{*}{$\begin{array}{l}\text { Sind Danio } \\
\text { Devario devario }\end{array}$} & $10^{-4}$ & 80 & $1.6 \times 10^{7}$ \\
\hline & & $10^{-5}$ & 44 & $8.8 \times 10^{7}$ \\
\hline & & $10^{-6}$ & Less 30 & TFTC \\
\hline \multirow[t]{3}{*}{ Ruhi } & \multirow{3}{*}{$\begin{array}{l}\text { Rohu Carp/ Rohu } \\
\text { Labeo rohita }\end{array}$} & $10^{-4}$ & 64 & $1.28 \times 10^{7}$ \\
\hline & & $10^{-5}$ & Less 30 & TFTC \\
\hline & & $10^{-6}$ & Less 30 & TFTC \\
\hline \multirow{3}{*}{$\begin{array}{l}\text { Rup- } \\
\text { chada }\end{array}$} & \multirow{3}{*}{$\begin{array}{l}\text { Elongate glassy } \\
\text { perchlat } \\
\text { Pampus chunesis }\end{array}$} & $10^{-4}$ & 187 & $3.74 \times 10^{7}$ \\
\hline & & $10^{-5}$ & 87 & $1.74 \times 10^{8}$ \\
\hline & & $10^{-6}$ & 63 & $1.26 \times 10^{9}$ \\
\hline \multirow[t]{3}{*}{ Bhetki } & \multirow{3}{*}{$\begin{array}{l}\text { Barramund/Koral } \\
\text { Lates calarifer }\end{array}$} & $10^{-4}$ & 222 & $4.44 \times 10^{7}$ \\
\hline & & $10^{-5}$ & 166 & $3.32 \times 10^{8}$ \\
\hline & & $10^{-6}$ & 123 & $2.46 \times 10^{9}$ \\
\hline \multirow[t]{3}{*}{$\begin{array}{l}\text { Mola/ } \\
\text { Ulfa }\end{array}$} & $\begin{array}{l}\text { Mola craplet } \\
\text { Amblypharyngodon } \\
\text { mola }\end{array}$ & $10^{-4}$ & 203 & $4.06 \times 10^{7}$ \\
\hline & & $10^{-5}$ & 76 & $1.52 \times 10^{8}$ \\
\hline & & $10^{-6}$ & 47 & $9.4 \times 10^{8}$ \\
\hline \multirow[t]{3}{*}{ Cheli } & $\begin{array}{l}\text { Silver razorbe belly } \\
\text { minnow } \\
\text { Salmostoma acinaces }\end{array}$ & $10^{-4}$ & 141 & $2.82 \times 10^{7}$ \\
\hline & & $10^{-5}$ & 120 & $2.4 \times 10^{8}$ \\
\hline & & $10^{-6}$ & 105 & $2.1 \times 10^{9}$ \\
\hline \multirow[t]{3}{*}{ Baim } & \multirow{3}{*}{$\begin{array}{l}\text { Tixe track spiny ell } \\
\text { Mastacebelus armatus }\end{array}$} & $10^{-4}$ & 179 & $3.58 \times 10^{7}$ \\
\hline & & $10^{-5}$ & 121 & $2.42 \times 10^{8}$ \\
\hline & & $10^{-6}$ & Less 30 & TFTC \\
\hline \multirow{3}{*}{$\begin{array}{l}\text { Lak- } \\
\text { hoa/ } \\
\text { lokkha }\end{array}$} & \multirow{3}{*}{$\begin{array}{l}\text { Indian threadfin } \\
\text { Polynemus indicus }\end{array}$} & $10^{-4}$ & Over 300 & TNTC \\
\hline & & $10^{-5}$ & 105 & $2.1 \times 10^{8}$ \\
\hline & & $10^{-6}$ & Less 30 & TFTC \\
\hline \multirow{3}{*}{$\begin{array}{l}\text { Loitta/ } \\
\text { Lotey }\end{array}$} & Bombay Duck & $10^{-4}$ & Over 300 & TNTC \\
\hline & Harpadon nehereus & $10^{-5}$ & 290 & $5.8 \times 10^{8}$ \\
\hline & & $10^{-6}$ & 212 & $4.24 \times 10^{8}$ \\
\hline
\end{tabular}




\begin{tabular}{|c|c|c|c|c|}
\hline $\begin{array}{l}\text { Local } \\
\text { name }\end{array}$ & $\begin{array}{l}\text { Dried fish name } \\
\text { (Scientific Name) }\end{array}$ & $\begin{array}{l}\text { Dilu- } \\
\text { tion }\end{array}$ & $\begin{array}{l}\text { Number of } \\
\text { colonies }\end{array}$ & $\begin{array}{l}\text { Total via- } \\
\text { ble count } \\
\text { cfu/gm }\end{array}$ \\
\hline \multirow{3}{*}{$\begin{array}{l}\text { Kech- } \\
\text { hki }\end{array}$} & \multirow{3}{*}{$\begin{array}{l}\text { Ganges river sprat } \\
\text { Corica soborna }\end{array}$} & $10^{-4}$ & Over 300 & TNTC \\
\hline & & $10^{-5}$ & 256 & $5.12 \times 10^{8}$ \\
\hline & & $10^{-6}$ & 98 & $1.96 \times 10^{9}$ \\
\hline \multirow[t]{3}{*}{ Taki } & \multirow{3}{*}{$\begin{array}{l}\text { Spotted Snakehead } \\
\text { Channa punctatus }\end{array}$} & $10^{-4}$ & Over 300 & TNTC \\
\hline & & $10^{-5}$ & 284 & $5.68 \times 10^{8}$ \\
\hline & & $10^{-6}$ & 138 & $2.76 \times 10^{9}$ \\
\hline \multirow{3}{*}{$\begin{array}{l}\text { Chin- } \\
\text { gri }\end{array}$} & \multirow{3}{*}{$\begin{array}{l}\text { Shrimp/ Prawn } \\
\text { Penaneus monodon }\end{array}$} & $10^{-4}$ & 167 & $3.34 \times 10^{7}$ \\
\hline & & $10^{-5}$ & 54 & $1.08 \times 10^{8}$ \\
\hline & & $10^{-6}$ & Less 30 & TFTC \\
\hline \multirow{3}{*}{$\begin{array}{l}\text { Chap- } \\
\text { ila }\end{array}$} & \multirow{3}{*}{$\begin{array}{l}\text { Ganges river/ Indian } \\
\text { river shad } \\
\text { Gadusia chapra }\end{array}$} & $10^{-4}$ & Over 300 & TNTC \\
\hline & & $10^{-5}$ & 269 & $5.38 \times 10^{8}$ \\
\hline & & $10^{-6}$ & 187 & $3.74 \times 10^{9}$ \\
\hline
\end{tabular}

TNTC: Too numerous to count; TFTC: Too Ferw to Count.

\section{Frequency of isolated bacterial organism}

From 54 dried fish samples of 18 types fish showed $100 \%$ bacterial contamination. Total isolated organism was 168 from dried fish. In case 25 samples of cooked fish $20 \%$ were found contaminated, total isolated organisms were nine (9). Frequency of occurrence of Bacteria isolated from cooked fish samples were Escherichia coli $(\mathrm{n}=6) 66.66 \%$ and Shigella spp. $(\mathrm{n}=3)$ $33.34 \%$. The Figures 2 and 3 showed the frequency of organisms isolated from dried and cooked fish respectably.

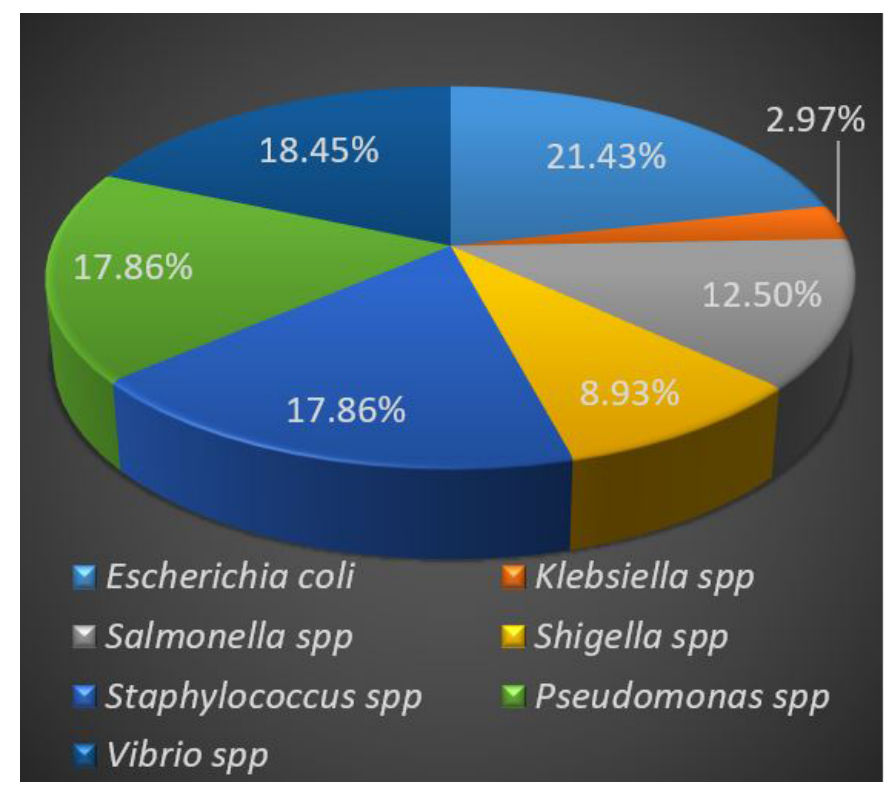

Figure 2: Frequency of isolated bacteria from dried fish.

\section{Results of antibiotics sensitivity tests}

Antimicrobial susceptibility testing was performed using Muller-Hinton agar (Mumbai, India) plates as recommended by the Clinical and Laboratory
Standards Institute. Seven (7) isolates of E. coli, Shigella spp., Klebsiella spp., Salmonella spp., Staphylococcus spp., Vibrio spp. and Pseudomonas spp. were subjected to antibiotic sensitivity tests for dried fish sample. Two isolates E. coli and Shigella spp. from cooked fish samples. The results of antibiotics sensitivity tests are presented in Tables 5, 6, 7.

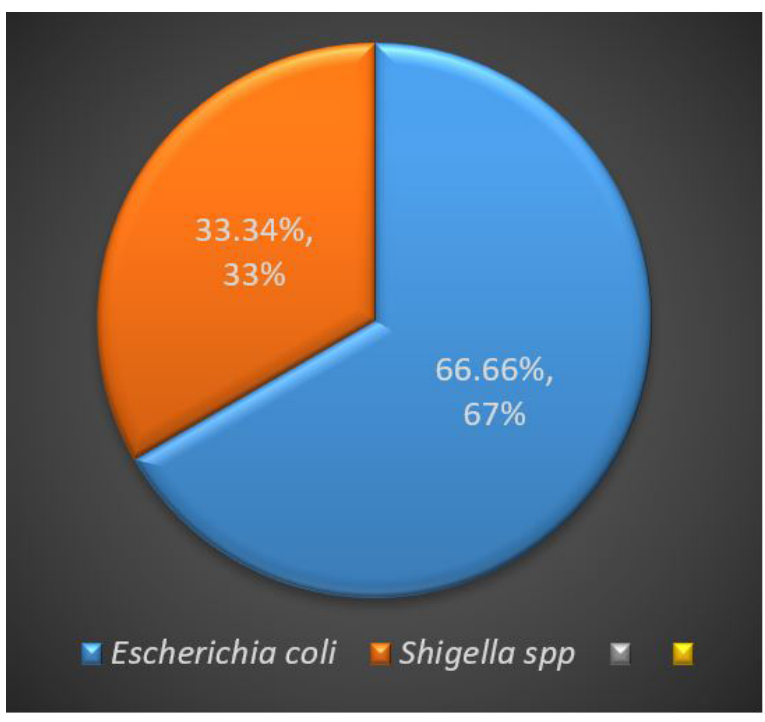

Figure 3: Frequency of isolated bacteria from cooked fish.

The experiment was carried out for detection and antibiogram study of bacterial pathogens isolated from 79 fish samples. Out of the 79 fish samples 54 samples were collected from dried fish and 25 samples were collected from cooked fish. There were 18 different types dried fish sample collected from the local fish markets and 6 different types cooked fish product from 15 different restaurants of Dinajpur city. For present study a series of test ware conducted for isolation, identification and antibiogram study of the isolated bacteria. For total aerobic viable microbial load detection Total Viable Plate Count was performed (TVC) in Plate Count Agar (PCA) media and counted by digital colony counter (Start Doc-It Colony Counter). The TVC result vary from $1.28 \times 10^{7} \mathrm{CFU} / \mathrm{g}$ to $3.74 \times 10^{9} \mathrm{CFU} / \mathrm{g}$. Highest microbial load found in Lottya and lowest TVC count in Ruhi dried fish sample. This study indicated that the different dried fish samples showed wide range of TVC which exceed accept level. Hazard Analysis and Critical Control Point-Total Quality Management (HACCP-TQM) technical guidelines rates microbial quality for raw foods containing aerobic plate count of $<10^{4} \mathrm{cfu} / \mathrm{g}$ as "Good", $10^{4}-5 \times 10^{6} \mathrm{cfu} / \mathrm{g}$ as "Average", $5 \times 10^{6}-5 \times 10^{7} \mathrm{cfu} / \mathrm{g}$ as "Poor" and $>5 \times 10^{7} \mathrm{cfu} / \mathrm{g}$ as "Spoilt" Which can be said to be extremely hazardous for public health. 
Table 2: TVC result of cooked fish sample.

$\begin{array}{llllll}\begin{array}{l}\text { Sample } \\ \text { No }\end{array} & \begin{array}{l}\text { Cooked fish } \\ \text { local name }\end{array} & \begin{array}{l}\text { Dried fish name } \\ \text { (Scientific Name) }\end{array} & \text { Dilution } & \begin{array}{l}\text { Number of } \\ \text { colonies }\end{array} & \begin{array}{l}\text { Total viable } \\ \text { count cfu/gm }\end{array} \\ \mathrm{S}_{1} \mathrm{R}_{1} & \text { Mirigel/Mirka } & \text { Mirgal Carp (Cirrbinus cirrbinus) } & 10^{-2} & 89 & 1.78 \times 10^{5} \\ \mathrm{~S}_{2} \mathrm{R}_{2} & \text { Chingri+Ptato Fry } & \text { Shrimp/ Prawn (Penaneus monodon) } & 10^{-3} & 71 & 1.42 \times 10^{6} \\ \mathrm{~S}_{3} \mathrm{R}_{3} & \mathrm{Ruhi} & \text { Rohu Carp/ Rohu (Labeo rohita) } & 10^{-2} & 63 & 1.26 \times 10^{5} \\ \mathrm{~S}_{4} \mathrm{R}_{4} & \text { Puti } & \text { Punti (Puntius sphore) } & 10^{-3} & 171 & 3.42 \times 10^{5} \\ \mathrm{~S}_{5} \mathrm{R}_{5} & \text { Ruhi } & \text { Rohu Carp/ Rohu (Labeo rohita) } & 10^{-2} & 98 & 1.96 \times 10^{5} \\ \mathrm{~S}_{6} \mathrm{R}_{6} & \text { Bata+ Potato } & \text { Labeo bata } & 10^{-2} & 123 & 2.48 \times 10^{5}\end{array}$

Table 3: Summary of isolated bacteria from different dried fish samples.

\begin{tabular}{|c|c|c|c|c|c|}
\hline Fish sample & Isolated presumptive organisms & $\begin{array}{l}\text { Fish sam- } \\
\text { ple }\end{array}$ & $\begin{array}{l}\text { Isolated presumptive } \\
\text { organisms }\end{array}$ & Fish sample & $\begin{array}{l}\text { Isolated presumptive } \\
\text { organisms }\end{array}$ \\
\hline Boal & $\begin{array}{l}\text { Escherichia coli } \\
\text { Salmonella spp. } \\
\text { Pseudomonas spp. } \\
\text { Vibrio spp. }\end{array}$ & Rup Chads & $\begin{array}{l}\text { Escherichia coli } \\
\text { Staphylococcus spp. } \\
\text { Salmonella spp. } \\
\text { Pseudomonas spp. } \\
\text { Vibrio spp. }\end{array}$ & Cheli & $\begin{array}{l}\text { Escherichia coli } \\
\text { Staphylococcus spp. } \\
\text { Pseudomonas spp. }\end{array}$ \\
\hline Shol/ Shoal & $\begin{array}{l}\text { Escherichia coli } \\
\text { Staphylococcus spp. } \\
\text { Shigella spp. } \\
\text { Pseudomonas spp. } \\
\text { Vibrio spp. }\end{array}$ & Bhetki & $\begin{array}{l}\text { Escherichia coli } \\
\text { Staphylococcus spp. } \\
\text { Salmonella spp. }\end{array}$ & Baim & $\begin{array}{l}\text { Escherichia coli } \\
\text { Salmonella spp. }\end{array}$ \\
\hline Baspata & Escherichia coli & Mola/ Ulfa & $\begin{array}{l}\text { Escherichia coli } \\
\text { Salmonella spp. }\end{array}$ & $\begin{array}{l}\text { Lakhoa/ } \\
\text { lokkha }\end{array}$ & $\begin{array}{l}\text { Escherichia coli } \\
\text { Staphylococcus spp. } \\
\text { Salmonella spp. } \\
\text { Vibrio spp. }\end{array}$ \\
\hline $\begin{array}{l}\text { Darikana/ } \\
\text { Dariki }\end{array}$ & $\begin{array}{l}\text { Staphylococcus spp. } \\
\text { Shigella spp. } \\
\text { Pseudomonas spp. }\end{array}$ & Ruhi & $\begin{array}{l}\text { Escherichia coli } \\
\text { Staphylococcus spp. } \\
\text { Pseudomonas spp. } \\
\text { Vibrio spp. }\end{array}$ & $\begin{array}{l}\text { Loitta/ } \\
\text { Lotey }\end{array}$ & $\begin{array}{l}\text { Klebsiella spp. } \\
\text { Vibrio spp. } \\
\text { Shigella spp. }\end{array}$ \\
\hline Ilish & $\begin{array}{l}\text { Escherichia coli } \\
\text { Staphylococcus spp. } \\
\text { Salmonella spp. } \\
\text { Pseudomonas spp. } \\
\text { Vibrio spp. }\end{array}$ & Churi & $\begin{array}{l}\text { Escherichia coli } \\
\text { Staphylococcus spp. } \\
\text { Pseudomonas spp. } \\
\text { Vibrio spp. }\end{array}$ & Kechhki & $\begin{array}{l}\text { Staphylococcus spp. } \\
\text { Klebsiella spp. } \\
\text { Shigella spp. } \\
\text { Pseudomonas spp. }\end{array}$ \\
\hline Taki & Vibrio spp. & Chingri & $\mathrm{N} / \mathrm{B}$ & Chapila & $\begin{array}{l}\text { Shigella spp. } \\
\text { Vibrio spp. } \\
\text { Pseudomonas spp. }\end{array}$ \\
\hline
\end{tabular}

Table 4: Summary of isolated bacteria from different cooked fish samples.

$\begin{array}{ll}\text { Cooked fish sample } & \text { Isolated presumptive organisms } \\ \text { Mirigel/Mirka } & \text { Escherichia coli } \\ \text { Chingri+Ptato Fry } & \text { Escherichia coli, Shigella spp. } \\ \text { Ruhi } & \text { Escherichia coli } \\ \text { Puti+Potato } & \text { Escherichia coli, Shigella spp. } \\ \text { Silver Carp } & \text { Escherichia coli } \\ \text { Bata+ Potato } & \text { Escherichia coli, Shigella spp. }\end{array}$

All samples were inoculated into various selective media such as Eosin Methylene Blue (EMB) agar, MacConkey agar, Salmonella Shigella (SS) agar, and Mannitol Salt (MS) agar, Cetrimide agar and Thiosulfate Citrate Bile Salts Sucrose (TCBA). Among 54 dried samples all (100\%) and 20\% of 25 cooked fish sample had found contaminated. A total of 168 bacterial isolates belong to seven genera (Staphylococcus spp., Vibrio spp., Escherichia coli, Klebsiella spp., Salmonella spp., Pseudomonas spp. and Shigella spp.) were identified from dried fish. The prevalence was $21.43 \%$ Escherichia coli,18.45\% Vibrio spp., 17.86\% Staphylococcus spp., 17.86\% Pseudomonas spp., 12.5\% Salmonella spp., 8.93\% Shigella spp. and 2.9\% Klebsiella spp. In case of cooked fish samples 9 bacterial isolates of two species (E.coli and Shigella spp.) 
Table 5: Results of antibiotic sensitivity test for gram negative organisms.

\begin{tabular}{llllllllll} 
Bacterial Species & \multicolumn{7}{c}{ Antibacterial agents and diameter of zone of inhibition (mm) with Interpretation } \\
& GEN & S & CH & E & CFM & CN & K & NA & CL \\
E. coli & $45(\mathrm{~S})$ & $37(\mathrm{~S})$ & $\mathrm{R}$ & $\mathrm{R}$ & $\mathrm{R}$ & $\mathrm{R}$ & $\mathrm{R}$ & $\mathrm{R}$ & $22(\mathrm{~S})$ \\
Shigella spp. & $18(\mathrm{~S})$ & $16(\mathrm{~S})$ & $\mathrm{R}$ & $\mathrm{R}$ & $14(\mathrm{I})$ & $\mathrm{R}$ & $22(\mathrm{~S})$ & $17(\mathrm{I})$ & $19(\mathrm{~S})$ \\
Klebsiella spp. & $35(\mathrm{~S})$ & $16(\mathrm{~S})$ & $\mathrm{R}$ & $\mathrm{R}$ & $\mathrm{R}$ & $\mathrm{R}$ & $\mathrm{R}$ & $\mathrm{R}$ & $27(\mathrm{~S})$ \\
Salmonella spp. & $28(\mathrm{~S})$ & $9(\mathrm{R})$ & $\mathrm{R}$ & $16(\mathrm{I})$ & $12(\mathrm{R})$ & $\mathrm{R}$ & $\mathrm{R}$ & $\mathrm{R}$ & $26(\mathrm{~S})$ \\
Pseudomonas spp. & $19(\mathrm{~S})$ & $\mathrm{R}$ & $8(\mathrm{R})$ & $39(\mathrm{~S})$ & $\mathrm{R}$ & $\mathrm{R}$ & $20(\mathrm{~S})$ & $\mathrm{R}$ & $\mathrm{R}$ \\
Vibrio spp. & $24(\mathrm{~S})$ & $20(\mathrm{~s})$ & $\mathrm{R}$ & $17(\mathrm{I})$ & $\mathrm{R}$ & $\mathrm{R}$ & $20(\mathrm{~S})$ & $15(\mathrm{I})$ & $\mathrm{R}$ \\
\hline
\end{tabular}

GEN: Gentamicin; S: Streptomycin; CH: Cephradine; E: Erythromycin; CFM: Cefixime; K: Kanamycin; NA: Nalidixic Acid; Cl: Colistin; I: Intermediate; S: Susceptible; R: Resistance.

Table 6: Results of antibiotic sensitivity test for gram positive organism.

\begin{tabular}{|c|c|c|c|c|c|c|c|c|c|}
\hline \multirow[t]{2}{*}{ Bacterial species } & \multicolumn{9}{|c|}{ Antibacterial agents diameter of zone of inhibition $(\mathrm{mm})$ interpretation } \\
\hline & GEN & $\mathbf{S}$ & $\mathbf{E}$ & AMX & CL & $\mathrm{AZM}$ & $\mathbf{P}$ & CXM & $\mathrm{CN}$ \\
\hline Staphylococcus spp. & $23(\mathrm{~S})$ & $18(\mathrm{~S})$ & $18(\mathrm{I})$ & $\mathrm{R}$ & $14(\mathrm{~S})$ & $22(\mathrm{~S})$ & $\mathrm{R}$ & $\mathrm{R}$ & $\mathrm{R}$ \\
\hline
\end{tabular}

G: Gentamycin; S: Streptomycin; E: Erythromycin; AMX: Amoxicillin; CL: Clindamycin; AZM: Azithromycin; P: Penicillin; G CXM: Cefuroxime Sodium; CN: Cephalexin; S: Sensitive; R: Resistant; -: No zone of inbibition.

Table 7: Result of antibiotic sensitivity test for gram negative organism isolated from cooked fish.

\begin{tabular}{llllllllll} 
Bacterial species & \multicolumn{7}{c}{ Antibacterial agents and diameter of zone of inhibition $(\mathbf{m m})$ with interpretation } \\
& GEN & S & CH & E & CFM & CN & K & NA & CL \\
E. coli & $41(\mathrm{~S})$ & $11(\mathrm{R})$ & $\mathrm{R}$ & $\mathrm{R}$ & $\mathrm{R}$ & $\mathrm{R}$ & $\mathrm{R}$ & $22(\mathrm{~S})$ & $22(\mathrm{~S})$ \\
Shigella spp. & $18(\mathrm{~S})$ & $16(\mathrm{~S})$ & $\mathrm{R}$ & $\mathrm{R}$ & $14(\mathrm{I})$ & $\mathrm{R}$ & $22(\mathrm{~S})$ & $17(\mathrm{I})$ & $19(\mathrm{~S})$
\end{tabular}

GEN: Gentamicin; S: Streptomycin; CH: Cephradine; E: Erythromycin; CFM: Cefixime; K: Kanamycin; NA: Nalidixic Acid; Cl: Colistin; I: Intermediate; S: Susceptible; R: Resistance.

were found with a prevalence $66.66 \%$ Escherichia coli and $33.34 \%$ Shigella spp. According to Hassan et al. (2021) highest occurrence was Staphylococcus spp., Bacillus spp., Salmonella spp. and E. coli. In the current work Staphylococcus sp., E. coli and Salmonella sp. notoriously appeared. Our findings are in agreement with the findings of Sulieman et al.(2014) in which they isolated Escherichia coli, Staphylococcus spp., Salmonella spp., Enterobacter cloacae, Klebsiella spp., Proteus spp., Bacillus cereus, Listeria monocytogenes, Vibrio parahaemolyticus, Vibrio cholerae and Pseudomonas spp. from dried fish. Logesh et al. (2012) also studied the microbiological quality of salted dried Marin fish according to their study they isolated Escherichia coli, Staphylococcus spp., Salmonella spp. and Vibrio cholerae which are known as human pathogenic organisms.

Above all reports are more or less similar to this experiment. Result of the present study indicates that all of the seven different types of bacteria were commonly present in dried cooked fish sample. The in vitro antibiotic sensitivity test of 7 different types of bacterial isolates to 9 different antibiotics for gram negative organisms such as gentamicin, streptomycin, cephalexin, erythromycin, cefixime, kanamycin, Cephradine, nalidixic acid, Colistin and 9 for gram positive organism such as gentamycin, Streptomycin, Erythromycin, Amoxicillin, Colistin, Azithromycin, Penicillin G, Cefuroxime Sodium and Cephalexin. The antibacterial sensitivity of isolates in this study to antibiotics was variable. Antimicrobial sensitivity test result showed that all of the sample harbor multidrug resistant food borne bacteria which might cause public health hazards if these antibiotic resistant transfer to human. Hence, it is recommended that a closer supervision of such food type should be carried out by relevant authorities to avoid any future pathogen outbreaks.

\section{Conclusions and Recommendations}

The present study was conducted for detection and antibiogram study of the bacteria isolated from different dried fishes and cooked fish samples. 
Presence of coliforms in the sample might be due to poor quality of water, unhygienic processing, handling, packaging transport, surrounding places and poor personal hygiene of personals involve in fish and fish product processing unit. Most dried fish producer and restaurant cook are illiterate and they did not have a clear hygienic knowledge about the preparation, storage and serving of the food. The results of this study suggested that a good source of animal protein may not be healthy due to lack of hygienic measures, dirty utensils, and cook 's hygiene. These factors contributing many species of bacteria but major pathogens are E. coli, Salmonella spp., Shigella spp., Klebsiella spp., Staphylococcus spp., Pseudomonas spp. and Vibrio spp. Basic and main source of bacterial infection is poor hygienic measures and this problem may be solved by improving supervision in food handling procedure, extended consumer education on transmission of enteric food borne diseases and food safety risks. So that fish drying and cooking should be manufactured under Good Hygienic Practices and conservation practices should be developed in order to minimize the microbial contamination of food.

\section{Acknowledgements}

Authors are really thankful to the Department of Microbiology, Faculty of Veterinary and Animal Science. HSTU, Bangladesh, for the laboratory support to this work.

\section{Novelty Statement}

Current research work helps to estimate the pathogenic bacteria in dried and cooked fish at Dinajpur, Bangladesh. This article independently focuses on the microbial load, quality of dried and cooked fish as well as creating public awareness against antimicrobial resistance (AMR). Lastly this work helps to aware about human health concern against fish born multi drug resistance bacteria.

\section{Author's Contribution}

All authors contributed to write and read the manuscript and agree to be responsible for any aspect of the manuscript.

\section{Conflict of interest}

The authors have declared no conflict of interest.

\section{References}

Ahmad, R., 2017. Fish revolution, Bangladesh sees 25 -fold growth in commercial fish farming in 3 decades. Daily Star., 9: 1-2. Available from: https://www.thedailystar.net/frontpage/fishrevolution-1445770

Austin, B., 2006. The bacterial microflora of fish, revised. Sci. World J., vol. 6. https://doi. org/10.1100/tsw.2006.181

Boylan, S., 2011. Zoonoses associated with fish. The veterinary clinics of North America. Exot. Anim. Pract., 14: 427-438. https://doi. org/10.1016/j.cvex.2011.05.003

Buxton, A., and Fraser, G., 1977. Animal microbiology. Vol. 1. Blackwell Scientific Publications, Oxford, London, Edinburg, Melbourne. pp. 400-480.

Cappuccino, J.G., and Sherman, N., 1996. Microbiology a laboratory manual. The Benjamin Cummings Publishing Co. Inc., San Francisco.

DoF, 2016. National fish week, compendium (In Bengali). Dhaka: Department of Fisheries, Ministry of Fisheries and Livestock, Government of Bangladesh.

DoF, 2017. Annual report 2017 Dhaka. Department of Fisheries, Ministry of Fisheries and Livestock, Government of Bangladesh.

EUCAST, 2015. Breakpoint tables for interpretation of MICs and zone diameters, version 5.0.

FAO, 2016. Food and Agriculture Organization of United Nation. The State of World Fisheries and Aquaculture 2016 (SOFIA). 176-182. Available here: http://www.fao.org/3/a-i5555e. pdf

Hassan, M.K., Poppy, M., Ahamed, T., Morsheda, F., Yadav, R., Hasan, A., and Siddique, M.P., 2021. Bacterial flora isolated from dried fishes sold at retail markets within Dhaka city corporation of Bangladesh. Res. Agric. Livest. Fish., 8(1): 109-115. https://doi.org/10.3329/ ralf.v8i1.53272

Hudzicki, J., 2009. Kirby-Bauer disk diffusion susceptibility test protocol. Am. Soc. Microbiol.,

ISO, 1995. Recommendation of the meeting of the subcommittee, International Organization for Standardization, on meat and meat products. ISO/TC-36/Sc-6. The Netherlands. pp. 10-18. Logesh, A.R., Pravinkumar, M., Raffi, S.M., and Kalaiselvam, M., 2012. An investigation on 
microbial screening on salt dried marine fishes. J. Food Resour. Sci., 1(1): 15-21. https://doi. org/10.3923/jfrs.2012.15.21

Merchant, I.A., and Packer, R.A., 1967. Veterinary bacteriology and virology. $7^{\text {th }}$ edition, The Iowa University Press, Ames, IA, pp. 286-306.

Mozumder, M.M.H., Uddin, M.M., Schneider, P., Islam, M.M., Shamsuzzaman, M., 2018. Fisheries-based ecotourism in Bangladesh. Potentials and challenges. Resources, 7(4): 61. https://doi.org/10.3390/resources7040061

Novotny, L., Dvorska, L., Lorencova, A., Beran, V., and Pavlik, I., 2017. Fish: a potential source of bacterial pathogens for human beings. A review. Veterinarni Medicina-UZPI (Czech Republic). 2004. Present status and future direction. Aquac. Fish., 2017 May 23.

Pal, M., Ketema, A., Anberber, M., Mulu, S., and Dutta, Y., 2016. Microbial quality of fish and fish products. Beverage Food World, 43(2): 46-
49.

Shamsuzzaman, M.M., Islam, M.M., Tania, N.J., Al-Mamun, M.A., Barman, PP., and $\mathrm{Xu}$, X., 2017. Fisheries resources of Bangladesh: Present status and future direction. Aquac. Fish., 2(4): 145-156. https://doi.org/10.1016/j. aaf.2017.03.006

Sohana, S.A., and Karim, M.E., 2016. Microbiological quality assessment of frozen fish and fish processing materials from Bangladesh international scholarly research; Available from: http://www.hindawi.com/ jpurnals/ijfs/2016/8605689/cta https://doi. org/10.1155/2016/8605689

Sulieman, A.M., Hassan, Z.M., and Elkhalifa, E.A., 2014. Microbial safety of dried fish meat (Kejeik) produced in Sudan. Food Nutr. Sci., 5(7): 606. https://doi.org/10.4236/ fns.2014.57071 